\title{
REDUPLIKASI VERBA BAHASA MELAYU JAMBI \\ DI DESA NIASO KECAMATAN MARO SEBO \\ KABUPATEN MUARO JAMBI \\ (KAJIAN MORFOSINTAKSIS)
}

\author{
Firman Tara $^{1}$, Desi Ratna Sari ${ }^{2}$ \\ Program Studi Pendidikan Bahasa dan Sastra Indonesia, \\ Fakultas Keguruan dan Ilmu Pendidikan, Universitas Batanghari, \\ Jambi
}

firmantara14@gmail.com

ratnasaridesi67@gmail.com

\begin{abstract}
This research is aimed at describing the use of repetition words from the aspect of form, process, and meaning. This research is qualitative descriptive. The data is taken from the quotation of words which are required from data source. The data source is the native speaker of Jambi Malay who live in Niaso village Kecamatan Maro Sebo Kabupaten Muaro Jambi. The data is collected by using observation, listening, speaking, and writing. The data is analyzed by using direct technique. The result of this research shows that there are 4 reduplications, namely (1) whole reduplication, (2) half reduplication, (3) affixes reduplication, (4) change of phoneme reduplication. There is also one meaning in this reduplication which is stating a work.
\end{abstract}

Keywords : Analysis, Verb Reduplication, Jambi Malay Language

\footnotetext{
${ }^{1}$ Dosen Program Studi Pendidikan Bahasa dan Sastra Indonesia, Fakultas Keguruan dan Ilmu Pendidikan Universitas, Batanghari Jambi, Jambi

${ }^{2}$ Mahasiswa Program Studi Pendidikan Bahasa dan Sastra Indonesia, Fakultas Keguruan dan Ilmu Pendidikan Universitas Batanghari, Jambi
}

Reduplikasi Verba Bahasa Melayu Jambi di Desa Niaso Kecamatan Maro Sebo Kabupaten Muaro Jambi (Kajian Morfosintaksis) 


\section{PENDAHULUAN}

Indonesia merupakan Negara terbesar yang memiliki keanekaragaman budaya, salah satu keanekaragaman itu merupakan bahasa-bahasa yang ada di Indonesia. Bahasa merupakan alat komunikasi antarmanusia, dalam bentuk ucapan, pikiran, dan perasaan sehingga dapat dimengerti orang lain. Bahasa memegang peranan penting dalam kehidupan sehari-hari di antaranya sebagai alat pemersatu bangsa atau identitas bangsa. Hal ini tampak dari berbagai aktivitas yang dilakukan manusia, bahasa senantiasa dijadikan rangka untuk mencapai tujuan. Bahasa juga dapat mengomunikasikan berbagai aspek kehidupan dalam arti luas.

"Bahasa ialah alat komunikasi antara anggota masyarakat berupa simbol bunyi yang dihasilkan oleh alat ucap manusia” (Keraf, 1997: 1). Bahasa juga berfungsi sebagai alat komunikasi yang bersifat arbitrer. Bahasa selain sebagai alat komunikasi dan interaksi sosial, juga mempunyai peranan sebagai alat untuk melakukan kegiatan-kegiatan kebudayaan sekaligus juga merupakan bagian dari kebudayan itu sendiri. Salah satu wujud kebudayaan adalah bahasa daerah.

Bahasa daerah merupakan warisan budaya nasional yang jelas. Negara berkewajiban untuk ikut serta mengembangkan nilai-nilai budaya yang terkandung di dalamnya. Sejalan dengan paparan ini maka diperlukan penelitian berupa pendokumentasian hasil garapan terhadap bahasa daerah dengan maksud melestarikan nilai-nilai luhur bahasa bangsa ini tidak mengalami kepunahan, karena punahnya salah satu bahasa daerah, sama halnya dengan hilangnya salah satu unsur budaya.

Sehubungan dengan penyataan di atas maka upaya melakukan penelitian terhadap bahasa-bahasa daerah di seluruh Indonesia sangat dibutuhkan. Upaya tersebut, merupakan suatu wujud kepedulian masyarakat untuk menjaga dan tetap melestarikan bahasa-bahasa daerah yang ada di Indonesia, termasuk di dalamnya yaitu bahasa Melayu Jambi. Dalam situs Wikipedia disebutkan bahwa "Bahasa Melayu Jambi adalah salah satu anak cabang bahasa Austronesia yang dituturkan khususnya di wilayah Jambi, bagian selatan provinsi Riau serta terbesar di berbagai kota di seluruh Indonesia”.

Bahasa Melayu Jambi merupakan salah satu bahasa yang digunakan oleh sebagian masyarakat yang ada di Provinsi Jambi. Rahima (2002:1) mengatakan bahwa "bahasa Melayu dipakai untuk berkomunikasi antarsuku dan warga masyarakat secara nonformal, juga dipakai sebagai alat komunikasi resmi yang sarat dengan nilai-nilai budaya, seperti dalam upacara pertunangan, dan pernikahan. Satu di antara daerah di Provinsi Jambi yang menggunkan bahasa Melayu adalah Desa Niaso Kecamatan Maro Sebo Kabupaten Muaro Jambi. Bahasa yang digunakan dalam kehidupan sehari-hari oleh masyarakat Desa Niaso sebagai alat komunikasi dan berinteraksi antara individu yang satu dengan individu yang lainnya.

Penelitian ini menganalisis tentang penggunaan reduplikasi bahasa Melayu Jambi di Desa Niaso Kecamatan Maro Sebo Kabupaten Muaro Jambi. Secara geografis Desa Niaso terletak di dalam daerah Kecamatan Maro Sebo Kabupaten Muaro Jambi dengan luas wilayah $\pm 305,50 \mathrm{Ha} / \mathrm{M} 2$. Sebelah Timur Desa Niaso berbatasan dengan Desa Kunangan Kecamatan Taman Rajo, sebelah Utara berbatasan dengan Desa Tanjung Johor Kecamatan Pelayangan, sebelah Selatan berbatasan dengan Desa Bakung Kecamatan Maro Sebo, sebelah Barat berbatasan dengan Desa Danau Kedap Kecamatan Maro Sebo. 
Masyarakat di Desa Niaso merupakan masyarakat multikultural yang terbentuk karena transmigrasi, yang terdiri dari masyarakat penutur asli, Jawa, Sumatra Barat, dan Sumatra Utara. Masyarakat transmigrasi ini umumnya bekerja sebagai pedagang yang menjual beraneka ragam kebutuhan untuk masyarakat Desa Niaso, dan orang asli Desa Niaso bekerja sebagai petani dan peternak.

Perkembangan ilmu pengetahuan dan teknologi yang semakin canggih, mengakibatkan perkembangan bahasa daerah dengan munculnya kata-kata atau istilah baru yang mengakibatkan berkurangnya keaslian bahasa Melayu di Desa Niaso, Remaja di Desa Niaso sering mengunakan bahasa-bahasa gaul yang secara sengaja telah merusak bahasa daerahnya. Bahkan banyak pendatang yang berbahasa daerah lain menetap di Desa Niaso sehingga bahasa daerah Niaso bercampur dengan bahasa daerah lain yang dibawa oleh pendatang tersebut, khususnya pada pengulangan kata atau reduplikasi.

Untuk memperlancar komunikasi, penduduk Desa Niaso menggunakan bahasa Indonesia kemelayu-melayuan, yang secara tidak langsung berpengaruh terhadap bahasa Melayu Jambi yang digunakan oleh masyarakat Melayu Desa Niaso, akibatnya komunikasi antara masyarakat Melayu dengan pendatang yang berada di Kabupaten Muaro Jambi tercampur, untuk memahami tuturan masyarakat secara keseluruhan, perlu diperhatikan dan dipelajari unsur-unsur yang membentuk ujaran tersebut. Mulai dari unsur pembentukan kalimat terkecil sampai unsur yang paling besar. Selain itu, satuan unsur pembentukan kalimat juga perlu diperhatikan seperti klausa, frasa, dan kata. Dengan demikian, dari unsur-unsur tersebut akan menentukan makna ujaran yang dikemukakan.
Kajian tentang seluk beluk kata ini termasuk dalam kajian morfologi. Rofii dan Franscy (2018:7) mengatakan bahwa in the morphology, described the process of word formation, said forming tool, class of words, meanings of words, as well as changes in the sound produced by the morphological process Pada kajian morfologi kata ulang disebut Reduplikasi. Reduplikasi yaitu proses pengulangan kata. "Proses pengulangan merupakan peristiwa pembentukan kata dengan jalan mengulang bentuk dasar, baik secara seluruhnya maupun sebagian baik bervariasi fonem maupun tidak, baik berkombinasi dengan afiks maupun tidak” (Muslich, 2008 :48).

Di Desa Niaso Kecamatan Maro Sebo Kabupaten Muaro Jambi juga di temukan banyak reduplikasi, contohnya pada kata (1) kulu-keler (bolak-balik) urutan proses reduplikasi perubahan fonem kulu (bentuk dasar) $\rightarrow$ keler (perubahan) $\rightarrow$ kulu-keler (reduplikasi) bentuk reduplikasi dengan perubahan fonem (makna perbuatan), (2) degeldegel (nakal-nakal) urutan proses reduplikasi adjektiva seluruh degel (bentuk dasar) $\rightarrow$ degel-degel (reduplikasi) bentuk reduplikasi seluruh (makna sifat), (3) elok-elok (cantikcantik) urutan proses reduplikasi adjektiva cantik (bentuk dasar) $\rightarrow$ cantikcantik (reduplikasi) bentuk reduplikasi seluruh (makna sifat), dan (4) gedanggedang (besar-besar) urutan proses reduplikasi adjektiva gedang (kata dasar) $\rightarrow$ gedang-gedang (reduplikasi) bentuk reduplikasi seluruh (makna sifat). Contoh kata ulang ini sudah sedikit penggunanya. Sehingga tanpa disadari bahasa daerah di Desa Niaso Kecamatan Maro Sebo Kabupaten Muaro Jambi semakin terkikis.

Pada penelitian ini difokuskan pada bentuk dan makna reduplikasi yang terdapat dalam bahasa Melayu Jambi di 
Desa Niaso Kecamatan Maro Sebo Kabupaten Muaro Jambi. Berdasarkan beberapa penjelasan tersebut, penelitian ini focus kepada analisis reduplikasi verba bahasa Melayu Jambi di Desa Niaso Kecamatan Maro Sebo Kabupaten Muaro Jambi (kajian morfosintaksis).

Penelitian ini bertujuan untuk mendeskripsikan dan mendokumentasikan bentuk dan makna reduplikasi verba bahasa Melayu Jambi di Desa Niaso Kecamatan Maro Sebo Kabupaten Muaro Jambi. Selain hal tersebut, penelitian ini juga berusaha untuk menjawab beberapa pertanyaan, yaitu:

1. Bagaimana bentuk reduplikasi verba bahasa Melayu Jambi di Desa Niaso Kecamatan Maro Sebo Kabupaten Muaro Jambi?

2. Bagaimana proses reduplikasi verba bahasa Melayu Jambi di Desa Niaso Kecamatan Maro Sebo Kabupaten Muaro Jambi?

3. Bagaimana makna reduplikasi verba bahasa Melayu Jambi di Desa Niaso Kecamatan Maro Sebo Kabupaten Muaro Jambi?

\section{METODE PENELITIAN}

Jenis penelitian ini adalah deskriptif kualitatif. Arikunto (2010 :3), mengatakan "Penelitian deskriptif adalah penelitian yang dimaksudkan untuk menyelidiki keadaan, kondisi atau hal-hal lain, yang hasilnya dipaparkan dalam bentuk laporan penelitian”. Bogdan dan Taylor (dalam Muhammad, 2011 :30) mendefinisikan bahwa "Metodologi kualitatif sebagai prosedur penelitian yang menghasilkan data deskriptif berupa kata-kata tertulis atau lisan dari orangorang dan prilaku yang dapat diamati”. Penelitian kualitatif selalu bersifat deskriptif yang artinya data yang dianalisis berbentuk gejala atau fenomena-fenomena, tidak berupa angkaangka.

Teknik pengumpulan data merupakan cara yang dapat digunakan oleh peneliti dalam mengumpulkan data untuk kepentingan penelitian. Teknikteknik pengumpulan data yang digunakan dalam penelitian ini adalah sebagai berikut:

(1) Observasi

"Observasi adalah dasar semua ilmu pengetahuan. Para Ilmuan hanya dapat bekerja berdasarkan data, yaitu fakta mengenai dunia kenyataan yang diperoleh melalui observasi” (Harun, 2007: 62). Metode observasi merupakan jenis penelitian dengan mengumpulkan data yang diperoleh berdasarkan pengamatan kangsung yang dilakukan di lapangan.

(2) Teknik Sadap

Teknik sadap disebut teknik dasar dalam metode simak karena pada hakikatnya penyimakan diwujudkan dengan penyadapan. Dalam arti, peneliti dalam upaya mendapatkan data dilakukan dengan menyadap penggunaan bahasa seseorang atau beberapa orang yang menjadi informan (Mahsun, 2007: 242).

(3) Teknik Simak Libat Cakap

Pada teknik ini, peneliti melakukan penyadap dengan cara berpartisipasi sambil menyimak, berpartisipasi dalam pembicaraan, dan menyimak para informan. Dalam hal ini, peneliti terlibat langsung dalam dialog (Mahsun, 2007: 246).

(4) Teknik Catat

Teknik catat ini merupakan teknik lanjutan yang dilakukan ketika menerapkan metode simak dengan teknik lanjutan (teknik simak libat cakap dan teknik simak bebas libat cakap), yaitu mencatat data yang dapat diperoleh dari informan pada kartu data (Mahsun, 2007: 131). 
Teknik analisis dalam penelitian ini dilakukan dengen cara sebagai berikut:

1. mengklasifikasikan data;

2. mentabulasikan data;

3. menganalisis dan memberikan gambaran dalam bentuk deskriptif secara keseluruhan;

4. membuat kesimpulan dari hasil penelitian.

Dalam menganalisis data, penelitian ini juga menggunakan metode kajian distribusional. Djajasudarma (2010:69) menyatakan bahwa "Metode kajian distribusional yaitu metode yang menggunakan alat penentu unsur bahasa itu sendiri”. Ada dua teknik yang terdapat di dalam metode kajian distribusional, yaitu teknik bagi unsur langsung dan teknik urai unsur terkecil. Menurut Sudaryanto (1993: 31) “Teknik bagi unsur langsung merupakan teknik analisis data dengan membagi suatu konstruksi menjadi beberapa bagian atau konstituen”.

\section{HASIL DAN PEMBAHASAN}

Berdasarkan hasil penelitian yang dilakukan, dapat diketahui bahwa terdapat 4 bentuk reduplikasi bahasa Melayu Jambi yang ada di Desa Niaso Kecamatan Maro Sebo Kabupaten Muaro Jambi sebagai berikut. (1) Reduplikasi seluruh ialah reduplikasi yang mengulang bentuk dasar secara keseluruhan, tanpa ditambah atau diubah bentuk dasarnya, tanpa berimbuhan dan tanpa merubah fonemnya. (2) Reduplikasi sebagian ialah pengulangan bentuk dasar dengan mengulang sebagian dari bentuk dasarnya. (3) Reduplikasi berimbuhan ialah pengulangan bentuk dasar yang diikuti dengan proses pengimbuhan. (4) Reduplikasi dengan perubahan fonem ialah pengulangan bentuk dasar dengan disertai perubahan fonem.
Selanjutnya ditemukan juga proses reduplikasi yang terdapat dalam bahasa Melayu Jambi yang ada di Desa Niaso Kecamatan Maro Sebo Kabupaten Muaro Jambi, urutan proses atau proses pengulangan berupa terjadi proses reduplikasi dahulu kemudian afiksasi, dan terjadi afiksasi dahulu kemudian reduplikasi.

Ditemukan juga 1 makna yang terkandung dalam reduplikasi bahasa Melayu Jambi yang ada di Desa Niaso Kecamatan Maro Sebo Kabupaten Muaro Jambi, yaitu: menyatakan pekerjaan.

\section{Bentuk Reduplikasi Bahasa Melayu Jambi di Desa Niaso Kecamatan Maro Sebo Kabupaten Muaro Jambi}

Terdapat empat bentuk reduplikasi yang ada dalam bahasa Melayu Jambi di Desa Niaso Kecamatan Maro Sebo Kabupaten Muaro Jambi, yaitu: (1) reduplikasi seluruh, (2) reduplikasi sebagian, (3) reduplikasi berimbuhan, dan (4) reduplikasi perubahan fonem. Adapun urutan proses reduplikasi bahasa Melayu Jambi di Desa Niaso Kecamatan Maro Sebo Kabupaten Muaro Jambi dijelaskan sebagai berikut. Proses reduplikasi diawali dengan proses afiksasi pada bentuk dasar kemudian diikuti oleh reduplikasi, atau reduplikasi bentuk dasar terlebih dahulu baru kemudian mengalami proses afiksasi. Berikut adalah bentuk reduplikasi bahasa Melayu Jambi yang ada di Desa Niaso Kecamatan Maro Sebo Kabupaten Muaro Jambi.

\section{a. Reduplikasi Seluruh}

Muslich (2008:52) menyatakan "Reduplikasi seluruh adalah pengulangan yang mengulang bentuk dasar secara keseluruhan, tenpa ditambah atau diubah bentuk dasarnya, tanpa berimbuhan dan tanpa merubah fonemnya”. Berikut 
bentuk reduplikasi seluruh yang terdapat dalam bahasa Melayu Jambi di Desa Niaso Kecamatan Maro Sebo Kabupaten Muaro Jambi.

Reduplikasi verba seluruh adalah pengulangan bentuk dasar verba (kata kerja) secara keseluruhan, tanpa berimbuhan dan perubahan fonem. Berikut bentuk reduplikasi verba seluruh yang terdapat dalam bahasa Melayu Jambi di Desa Niaso Kecamatan Maro Sebo Kabupaten Muaro Jambi.

1) merse-merse "membersihkan"

2) ngota-ngota "bercerita"

3) nyatat-nyatat "mencatat-catat"

4) nyaet-nyaet "menjahit-jahit"

Reduplikasi verba merse-merse, ngota-ngota, nyatat-nyatat, dan nyaetnyaet merupakan reduplikasi verba seluruh karena bentuk dasarnya yang di ulang secara keseluruhan. Berdasarkan teori di atas, penulis formulasikan dalam wujud rumus-rumus yang digunakan sebagai dasar pembahasan. Maka Bentuk Reduplikasi verba di atas menggunakan tipe (BD+R).

\section{b. Reduplikasi Sebagian}

Muslich (2008:53) menyatakan Reduplikasi sebagian adalah pengulangan bentuk dasar secara sebagian, tanpa perubahan fonem. Berikut bentuk reduplikasi sebagian yang terdapat dalam bahasa Melayu Jambi di Desa Niaso Kecamatan Maro Sebo Kabupaten Muaro Jambi.

Reduplikasi verba sebagian adalah pengulangan bentuk dasar verba (kata kerja) secara sebagian, tanpa perubahan fonem. Berikut reduplikasi verba sebagian yang terdapat dalam bahasa Melayu Jambi di Desa Niaso Kecamatan Maro Sebo Kabupaten Muaro Jambi.

1) beimpan-impan "berkemas-kemas"

2) bejalan-jalan"jalan-jalan”

3) betinju-tinju“berpukul-pukulan”
4) beseol-seol"bersiul-siul"

5) begaot-gaot"menggaruk-garuk"

Reduplikasi verba sebagian yang terdapat di atas, beimpan-impan,bejalanjalan, betinju-tinju,beseol-seol, dan begaot-gaot dibentuk dari bentuk dasar imapan (kemas), jalan (jalan), tinju (pukul), seol (siul), dan gaot (garuk). Bentuk reduplikasi verba sebagian pada data di atas dapat dikelompokkan dalam pengulangan atau reduplikasi sebagaian, karena bentuk dasarnya yang diulang secara sebagian. Berdasarkan teori di atas, penulis formulasikan dalam wujud rumus-rumus yang digunakan sebagai dasar pembahasan. Maka bentuk reduplikasi verba di atas menggunakan tipe $((\mathrm{D}+b e-)+\mathrm{R})$.

\section{c. Reduplikasi Berimbuhan}

Muslich (2008:53) menyatakan reduplikasi berimbuhan adalah pengulangan bentuk dasar disertai dengan pembubuhan afiks. Afiks atau imbuhan adalah bunyi yang ditambahkan pada sebuah kata, berikut reduplikasi berimbuhan yang terdapat dalam bahasa Melayu Jambi di Desa Niaso Kecamatan Maro Sebo Kabupaten Muaro Jambi.

Reduplikasi verba berimbuhan dapat berupa reduplikasi bentuk dasar yang diikuti afiksasi berupa sufiks-an. Uraian tersebut dapat dilihat pada data di bawah ini.

1) tedok-tedokan"tidur-tiduran”

2) maap-maapan"maaf-maafan"

3) bebunu-bunuan"berbunuhan”

Reduplikasi tedok-tedokan, maap-maapan dan bebunu-bunuan pada data di atas dibentuk dari bentuk dasar verba tedok (tidur), maap (maaf), dan bunu (bunuh). Bentuk reduplikasi verba pada data di atas dikelompokkan dalam reduplikasi berimbuhan karena bentuk dasarnya yang mengalami proses reduplikasi dan diikuti afikasasi berupa sufiks-an. Berdasarkan teori di atas, dapat 
diformulasikan dalam wujud rumusrumus yang digunakan sebagai dasar pembahasan. Bentuk reduplikasi verba tersebut menggunakan tipe $((\mathrm{D}+\mathrm{R})+-a n)$.

\section{d. Reduplikasi dengan Perubahan Fonem}

Muslich (2008:54) menyatakan reduplikasi dengan perubahan fonem adalah pengulangan bentuk dasar dengan disertai perubahan fonem. Berikut reduplikasi verba berimbuhan yang terdapat dalam bahasa Melayu Jambi di Desa Niaso Kecamatan Maro Sebo Kabupaten Muaro Jambi.

1) kulu-keler"bolak-balik"

2) pontang-panteng“pontang-panting”

Bentuk reduplikasi kulu-keler, dan pontang-panteng, pada data di atas dibentuk dari bentuk dasar kulu (bolak), dan panteng (panting). Pada bentuk reduplikasi tersebut terjadi pengulangan serta pembubuhan fonem secara bersamaan. Oleh karena itu hasil reduplikasinya dikelompokkan dalam pengulangan yang mengalami perubahan fonem. Berdasarkan teori di atas, dapat diformulasikan dalam wujud rumusrumus yang digunakan sebagai dasar pembahasan. Maka Bentuk reduplikasi tersebut menggunakan tipe (D+Rpref).

Pembentukan kata tersebut dimulai dengan kata dasar yang langsung menjadi bentuk dasar, dan mengalami proses reduplikasi yang langsung diikuti perubahan fonem secara bersamaan. Dari data di atas dapat dilihat misalnya: pada kata kulu-keler, pada kata tersebut terdapat perubahan fonem /u/ menjadi fonem /e/ dan penambahan fonem / $\mathrm{r}$, pada kata bolak-balek, terdapat perubahan fonem /o/ menjadi fonem /a/ dan fonem /a/ menjadi fonem /e/, pada kata pontang-panteng terdapat perubahan fonem /o/ menjadi fonem /a/ dan fonem /a/ menjadi fonem /e/. Bentuk dasar dari kata di atas terletak pada komponen pertama, sehingga prosesnya terjadi dari arah kanan ke kiri sesuai dengan ujarannya, proses seperti ini dinamakan reduplikasi progresif.

\section{Proses Reduplikasi Bahasa Melayu Jambi di Desa Niaso Kecamatan Maro Sebo Kabupaten Muaro Jambi}

Adapun urutan proses reduplikasi bahasa Melayu Jambi di Desa Niaso Kecamatan Maro Sebo Kabupaten Muaro Jambi dijelaskan sebagai berikut. Proses reduplikasi diawali dengan proses afiksasi pada bentuk dasar kemudian diikuti oleh reduplikasi, atau reduplikasi bentuk dasar terlebih dahulu baru kemudian mengalami proses afiksasi. Berikut adalah bentuk reduplikasi bahasa Melayu Jambi yang ada di Desa Niaso Kecamatan Maro Sebo Kabupaten Muaro Jambi.

\section{a. Reduplikasi Seluruh}

Muslich (2008:52) menyatakan "Reduplikasi seluruh adalah pengulangan yang mengulang bentuk dasar secara keseluruhan, tanpa ditambah atau diubah bentuk dasarnya, tanpa berimbuhan dan tanpa merubah fonemnya”. Berikut proses reduplikasi verba seluruh yang terdapat dalam bahasa Melayu Jambi di Desa Niaso Kecamatan Maro Sebo Kabupaten Muaro Jambi.

bentuk dasar $\rightarrow$ reduplikasi utuh $\rightarrow$ kata bereduplikasi
1) berseh (dasar) $\rightarrow$ berseh-berseh (reduplikasi)
2) cerito (dasar) $\rightarrow$ cerito-cerito (reduplikasi)
3) nyatat (dasar) $\rightarrow$ nyatat-nyatat (reduplikasi)
4) nyaet (dasar) $\rightarrow$ nyaet-nyaet (reduplikasi)


5) ngali (dasar) $\rightarrow$ ngali-ngali (reduplikasi)

Pembentukan kata tersebut dimulai dengan bentuk dasar verba (baik yang mengalami proses afiksasi maupun yang tidak); kemudian dari bentuk dasar tersebut mengalami proses reduplikasi secara keseluruhan; proses reduplikasi yang berlangsung ke arah kanan atau sesuai dengan arah ujaran seperti contoh tersebut disebut reduplikasi progresif.

\section{b. Reduplikasi Sebagian}

Muslich (2008:53) menyatakan "Reduplikasi sebagian adalah pengulangan bentuk dasar secara sebagian, tanpa perubahan fonem”. Berikut proses reduplikasi sebagian yang terdapat dalam bahasa Melayu Jambi di Desa Niaso Kecamatan Maro Sebo Kabupaten Muaro Jambi.

kata dasar $\rightarrow$ bentuk dasar $\rightarrow$ reduplikasi sebagian $\rightarrow$ kata bereduplikasi (prefiks)

1) impan (dasar) $\rightarrow$ beimpan (bentuk dasar) $\rightarrow$ beimpan-impan (reduplikasi)

2) jalan (dasar) $\rightarrow$ bejalan (bentuk dasar) $\rightarrow$ bejalan-jalan (reduplikasi)

3) tinju (dasar) $\rightarrow$ betinju (bentuk dasar) $\rightarrow$ betinju-tinju (reduplikasi)

4) seol (dasar) $\rightarrow$ beseol (bentuk dasar) $\rightarrow$ beseol-seol (reduplikasi)

5) gaot (dasar) $\rightarrow$ begaot (bentuk dasar) $\rightarrow$ begaot-gaot (reduplikasi)

Pembentukan kata tersebut dimulai dengan kata dasar yang berubah menjadi bentuk dasar verba setelah melalui proses afiksasi berupa (prefiks be-); kemudian dilanjutkan dengan proses reduplikasi sebagian dari bentuk dasarnya; proses reduplikasi yang berlangsung dari kiri ke kanan atau sesuai dengan arah ujaran tersebut disebut reduplikasi progresif.

\section{c. Reduplikasi Berimbuhan}

Muslich (2008:53) menyatakan Reduplikasi berimbuhan adalah pengulangan bentuk dasar disertai dengan pembubuhan afiks. Afiks atau imbuhan adalah bunyi yang ditambahkan pada sebuah kata, berikut proses reduplikasi berimbuhan yang terdapat dalam bahasa Melayu Jambi di Desa Niaso Kecamatan Maro Sebo Kabupaten Muaro Jambi.

Reduplikasi berimbuhan verba dapat berupa reduplikasi bentuk dasar yang diikuti afiksasi berupa sufiks -an. Uraian tersebut dapat dilihat pada data berikut ini.

bentuk dasar $\rightarrow$ reduplikasi $\rightarrow$ afiksasi

$\rightarrow$ kata bereduplikasi

1) tedok (bentuk dasar) $\rightarrow$ tedok-tedok (reduplikasi) $\rightarrow$ tedok-tedokan (afiksasi)

2) maap (bentuk dasar) $\rightarrow$ maap-maap (reduplikasi) $\rightarrow$ maap-maapan (afiksasi)

3) bunu(bentuk dasar) $\rightarrow$ bebunu-bunu (reduplikasi) $\rightarrow$ bebunu-bunuan (afiksasi)

Pembentukan kata tersebut dimulai dengan bentuk dasar yang mengalami proses reduplikasi; kemudian dilanjutkan dengan proses afiksasi berupa (sufiks -an). Proses reduplikasi yang terjadi ke arah sebelah kanan tersebut disebut reduplikasi progresif.

\section{d. Reduplikasi dengan Perubahan Fonem}

Muslich (2008:54) menyatakan "Reduplikasi dengan perubahan fonem adalah pengulangan bentuk dasar dengan disertai perubahan fonem”. Berikut proses reduplikasi berimbuhan yang terdapat dalam Bahasa Melayu Jambi di 
Desa Niaso Kecamatan Maro Sebo Kabupaten Muaro Jambi.

bentuk dasar $\rightarrow$ reduplikasi dan perubahan $\rightarrow$ kata bereduplikasi fonem atau (rpref)

1) kulu (bentuk dasar) $\rightarrow$ keler (perubahan) $\rightarrow$ kulu-keler (reduplikasi)

2) bolak (bentuk dasar) $\rightarrow$ balek (perubahan) $\rightarrow$ bolak-balek (reduplikasi)

3) pontang (bentuk dasar) $\rightarrow$ panteng (perubahan) $\rightarrow$ pontang-panteng (reduplikasi)

Pembentukan kata tersebut dimulai dengan kata dasar yang langsung menjadi bentuk dasar, kemudian mengalami proses reduplikasi yang langsung diikuti perubahan fonem secara bersamaan. Dari data di atas dapat kita lihat misalnya: pada kata kulu-keler, pada kata tersebut terdapat perubahan fonem /u/ menjadi fonem /e/ dan penambahan fonem /r/, pada kata bolak-balek, terdapat perubahan fonem /o/ menjadi fonem /a/ dan fonem /a/ menjadi fonem /e/, pada kata pontang-panteng terdapat fonem /o/ menjadi fonem /a/ dan fonem /a/ menjadi fonem /e/. Bentuk dasar dari kata di atas terletak pada komponen pertama, sehingga prosesnya terjadi dari arah kanan ke kiri sesuai dengan ujarannya, proses seperti ini dinamakan reduplikasi progresif.

\section{Makna Reduplikasi Verba Bahasa Melayu Jambi Desa Niaso Kecamatan Maro Sebo Kabupaten Muaro Jambi}

Reduplikasi dalam pemakaian kalimat bahasa Melayu Jambi di Desa Niaso Kecamatan Maro Sebo Kabupaten Muaro Jambi, menghasilkan makna yaitu: menyatakan 'pekerjaan', untuk lebih jelasnya dapat dikemukakan contoh pada uraian berikut.

1) berseh-berseh"bersih-bersih"

2) nyaet-nyaet"menjahit"

3) ngali-ngali“menggali-gali”

4) beimpan-impan"berkemas-kemas"

5) tedok-tedokan"tidur-tiduran"

Dari beberapa contoh tersebut dapat diketahui bahwa reduplikasi berseh-berseh, nyaet-nyaet, ngali-ngali, beimpan-impan,dan tedok-tedokan menyatakan makna pekerjaan, yaitu pekerjaan bersih-bersih, pekerjaan menjahit, pekerjaan menggali, pekerjaan berkemas-kemas, dan pekerjaan tidurtiduran.

\section{SIMPULAN}

Sesuai dengan rumusan masalah yang telah dipaparkan, maka dapat disimpulkan bahwa terdapat empat bentuk reduplikasi yaitu: 1) reduplikasi seluruh, (2) reduplikasi sebagian, (3) reduplikasi dengan pembubuhan afiks, (4) reduplikasi perubahan fonem.; empat proses reduplikasi yaitu: 1) reduplikasi seluruh, (2) reduplikasi sebagian, (3) reduplikasi berimbuhan, (4) reduplikasi perubahan fonem dan satu makna reduplikasi yaitu menyatakan pekerjaan.

\section{DAFTAR PUSTAKA}

Arikunto, Suharsimi. (2010). Prosedur Penelitian: Suatu Pendekatan Praktik. Jakarta: Rineka Cipta.

Djajasudarma, T. Fatimah. (2010). Metode Linguistik. Bandung: PT Refika Aditama.

Harun, Rochjat. (2007). Metode Penelitian Kualitatif Untuk Pelatihan. Bandung: Mandar Maju.

Keraf, Gorys. (1997). Komposisi Sebuah Pengantar Kemahiran Bahasa. Jakarta: Nusa Indah.

Mahsun. (2007). Metode Penelitian Bahasa: Tahapan Strategi, 
Metode, dan Tekniknya. Jakarta:

PT Raja Grafindo Persada.

Muhammad. (2011). Metode Penelitian

Bahasa. Yogyakarta: Ar-Ruzz

Media.

Muslich, Masnur. (2008). Tata Bentuk

Bahasa Indonesia. Jakarta: Bumi

Aksara.

Rahima, A. (2002). Sistem sapaan bahasa Melayu Jambi: laporan penelitian. Fakultas Keguruan dan Ilmu Pendidikan, Universitas Batanghari.

Rofii, Afif. dan Franscy. (2018). The Development of Contextual-Based Texbook on Morphological Process in Faculty of Teachers Training and Education Batanghari University Jambi. The Asian ESP Journal. Volume 14 Issue 2 Juli 2018. ISSN 22060979. https://www.asian-espjournal.com/2018/volume-14issue-2-july-2018/

Sudaryanto, (1993). Metode dan Aneka Teknik Analisis Bahasa: Pengantar Penelitian Wahana Kebudayaan Secara Linguistik. Yogyakarta: Muhammadiyah University Press.

Wikipedia.Reduplikasi.(http://id.wikipedi a.org/wiki/Reduplikasi). Diakses tanggal 13 November 2017. 